\title{
PENGARUH PEMBELAJARAN CAI-KONTEKSTUAL TERHADAP KEMAMPUAN BERPIKIR MATEMATIK DAN KARAKTER MAHASISWA
}

\author{
Nanang \\ Prodi Pendidikan Matematika STKIP Garut \\ na2ngdr.64@gmail.com
}

\begin{abstract}
The purpose of this study to determine the effect of CAI-Contextual learning of the ability to think mathematically and character of the student teacher participants of the course Capita Selecta Mathematical SMA. The population in this study is the fourth semester students of Mathematics Education STKIP Garut academic year 2015/2016. Selection of the sample by means of random sampling, the students obtained grade B as an experimental class and class A as the control class. Experimental class taught by CAI-Contextual learning, whereas the control class was taught by conventional learning. Retrieval of data obtained by the test method to get the data value of the initial knowledge of mathematics students and Mathematical Thinking Skills as well as the method of questionnaire to measure student character, and then analyzed with the average difference. The results showed that there are differences in the ability to think mathematically and character class students experiment with the control class. Since the average mathematical thinking skills and character students experimental class is bigger than the control class, it can be concluded that the CAI-Contextual learning positively affects the ability to think mathematically and character of the student teacher participants of the course Capita Selecta Mathematical SMA.
\end{abstract}

Keywords: CAI-Contextual, think mathematically, character.

ABSTRAK. Tujuan penelitian ini untuk mengetahui pengaruh pembelajaran CAIKontekstual terhadap kemampuan berpikir matematik dan karakter mahasiswa peserta mata kuliah Kapita Selekta Matematika SMA. Populasi dalam penelitian ini adalah mahasiswa semester 4 Program Studi Pendidikan Matematika STKIP Garut tahun akademik 2015/2016. Pemilihan sampel dengan cara random sampling, diperoleh mahasiswa kelas B sebagai kelas eksperimen dan kelas A sebagai kelas kontrol. Kelas eksperimen mendapatkan pembelajaran CAI-Kontekstual, sedangkan kelas kontrol mendapatkan pembelajaran konvensional. Pengambilan data diperoleh dengan metode tes untuk mendapatkan data nilai pengetahuan awal matematika (PAM) mahasiswa dan Kemampuan Berpikir Matematika (KBM) serta metode angket untuk mengukur karakter mahasiswa, kemudian dianalisis dengan uji perbedaan rata-rata. Hasil penelitian adalah terdapat perbedaan kemampuan berpikir matematik dan karakter mahasiswa kelas eksperimen dengan kelas kontrol. Karena rata-rata kemampuan berpikir matematik dan karakter mahasiswa kelas eksperimen lebih besar dari kelas kontrol, maka dapat disimpulkan bahwa pembelajaran CAI-Kontekstual berpengaruh positif terhadap kemampuan berpikir matematik dan karakter mahasiswa peserta mata kuliah Kapita Selekta Matematika SMA.

Kata Kunci: CAI-Kontekstual, berpikir matematik, karakter. 


\section{PENDAHULUAN}

Pembelajaran matematika di sekolah diharapkan dapat membuat peserta didik mampu menerapkan ilmu matematika yang dilandasi nilai-nilai ketaqwaan, kemandirian, dan kecerdasan dalam kehidupan sehari-hari. Hal ini didasarkan kepada pendapat Siswono (2012) bahwa para matematikawan terdahulu seperti Plato, Euclid, atau Mandelbrot telah mengaitkan matematika dengan keindahan, kreativitas, atau imajinasi dalam matematika. Pada dasarnya matematika humanistik melibatkan pengajaran yang isinya humanistik (humanistic content) dengan menggunakan pendidikanhumanistik (humanistic pedagogy) dalam keyakinan bahwa kekurangan motivasi siswamerupakan akar penyebab dari masalah-masalah sikap dan literasi dalam pendidikan matematika.Gerakannya adalah mencari kembali proses-proses pendidikan yang menyenangkan (excitement) dan menantang (wonderment) dengan kegiatan-kegiatan penemuan (discovery) dankreasi/karyacipta. Dengan demikian matematika humanistik mengarahkan pada pembelajaran yang memberikan keleluasaan siswa untuk belajar secara aktif yangmenyenangkan dan memberikan kebebasan siswa untuk tertantang melakukan kreasi-kreasi sehingga mendorong kreativitasnya.

Namun kenyataannya, pendidikan di Indonesia belum berhasil membuat peserta didik terampil dalam bermatematika. Hal ini tampak berdasarkan laporan TIMSS dari hasil skor rata-rata prestasi matematika kelas VIII SMP di Indonesia sebagai berikut.

Tabel 1. Peringkat Rata-rata Skor Matematika Kelas VIII Hasil Penilaian TIMSS

\begin{tabular}{ccccc}
\hline \multirow{2}{*}{ Tahun } & \multirow{2}{*}{$\begin{array}{c}\text { Banyak } \\
\text { Negara }\end{array}$} & $\begin{array}{c}\text { Peringkat } \\
\text { Indonesia }\end{array}$ & Internasional & Indonesia \\
\cline { 4 - 5 } & 38 & 34 & 487 & 403 \\
2003 & 46 & 35 & 467 & 411 \\
2007 & 49 & 36 & 500 & 397 \\
2011 & 42 & 38 & 500 & 386 \\
\hline
\end{tabular}

Sumber: Kemendikbud (2011) 
Dari Tabel 1, tampak bahwa rata-rata skor prestasi matematika peserta didik Indonesia pada TIMSS berada pada kategori Low International Benchmark atau di bawah skor rata-rata internasional.

Hal di atas pun terjadi pada rendahnya nilai mata kuliah Kapita Selekta Matematika SMA bagi mahasiswa Program Studi Pendidikan Matematika STKIP Garut. Mahasiswa tersebut banyak yang mengikuti program Semester Perbaikan (SP) pada mata kuliah Kapita Selekta Matematika SMA setiap tahunnya. Hal ini menunjukkan bahwa lemahnya kemampuan bermatematika juga dialami oleh mahasiswa calon guru matematika sendiri.

Lemahnya siswa maupun mahasiswa dalam bermatematika ada kemungkinan kurangnya dalam memahami konsep matematika yang diakibatkan oleh proses pembelajaran matematika yang masih lemah atau kurang efektif. Lemahnya proses pembelajaran matematika, kemungkinan disbabkan oleh guru matematika yang lebih dominan menggunakan model pembelajaran yang cenderung masih konvensional. Kekhasan dari pembelajaran konvensional menurut Ruseffendi (1991) lebih mengutamakan hafalan daripada pengertian, menekankan kepada keterampilan berhitung, mengutamakan hasil daripada proses, dan pengajarannya berpusat pada guru, sementara siswa pasif. Adapun kekhasan yang lainnya, yaitu interaksi seperti hanya dua arah, yaitu antara guru dan mahasiswa, guru sebagai sumber. Hal ini berarti pembelajaran matematika secara konvensional berfokus pada guru bukan pada siswa, ketergantungan siswa pada guru cukup besar, sedangkan kesempatan melakukan refleksi dan negosiasi melalui interaksi antara siswa dengan siswa atau siswa dengan guru kurang dikembangkan. Wahyudin (2012:393) menjelaskan bahwa metode-metode pengajaran matematika yang tradisional ini disoroti oleh NAEP dan TIMSS yaitu kurikulum matematika konvensional yang ditawarkan di Amerika Serikat menghasilkan siswa-siswa sekolah menengah yang tidak mampu melakukan perhitungan-perhitungan sederhana dan dengan demikian tidak mampu bersaing pada tingkat internasional.

Salah satu alternatif mengatasi lemahnya proses pembelajaran matematika adalah melalui pembelajaran kontekstual. Hal ini didasarkan saran Depdiknas 
(2006) bahwa dalam setiap kesempatan, pembelajaran matematika hendaknya dimulai dengan pengenalan masalah. Sementara menurut Suprijono (2014), mengaitkan materi pembelajaran (instructional content) dengan konteks kehidupan dan kebutuhan siswa akan meningkatkan motivasi belajarnya serta akan menjadikan proses belajar mengajar lebih efisien dan efektif. Pendekatan belajar tipe ini disebut pendekatan kontekstual (Contextual Teaching and Learning). Tugas guru dalam kelas kontekstual ini adalah membantu peserta didik mencapai tujuannya, maksudnya guru lebih banyak berurusan dengan strategi daripada memberi informasi. Tugas guru mengelola kelas sebagai sebuah tim yang bekerja sama untuk menemukan sesuatu yang baru bagi peserta didik.

Sementara Yaniawati (2010) menyarankan bahwa untuk meningkatkan efektivitas dan efisiensi dalam pembelajaran dan pengelolaan system pendidikan perlu mengaitkan atau memanfaatkan teknologi informasi.Tawaran yang diberikan teknologi menjanjikan cara-cara baru untuk mencapai tujuan-tujuan pendidikan/pembelajaran secara efektif dan efisien. Menurut Yaniawati (2010) pemanfaatan teknologi informasi selain sebagai upaya mengatasi permasalahan teknis pembelajaran, juga sebagai media pembelajaran dan sumber ajar. Melalui proses pembelajaran dengan memanfaatkan teknologi informasi, diharapkan peserta didik dapat mengembangkan diri secara mandiri dan kreatif. Apabila hal ini terjadi, maka peserta didik mendapatkan kesempatan melakukan proses konstruksi suatu pengetahuan baru melalui interaksi dengan peserta didik lainnya dan pendidik melalui sarana teknologi informasi (TI). Seiring dengan perkembangan dunia TI, Darmawan (2010) berkembanglah berbagai prosedur pengembangan dan peranan prinsip multimedia dalam pembelajaran dengan berbantuan komputer. Salah satu bahan ajar interaktif yang sering dikenal dengan pembelajaran berbasis komputer (Computer Assistance Instruction).

Isu lain lagi yaitu bahwa pendidikan di Indonesia selain belum berhasil membuat siswa terampil dalam menyelesaikan soal matematika yang memerlukan aplikasi dan penalaran, juga selama ini dirasakan proses pendidikan di Indonesia belum berhasil membangun manusia Indonesia yang berkarakter. Banyak lulusan sekolah dan sarjana yang mentalnya lemah, penakut, dan perilakunya tidak terpuji. 
Persoalan yang muncul di masyarakat seperti korupsi, kekerasan, kejahatan seksual, perusakan, perkelahian massa, kehidupan ekonomi yang konsumtif, kehidupan politik yang tidak produktif, dan sebagainya (BPP Puskur, 2010; Kesuma, dkk., 2011).

Berdasarkan uraian di atas, penulis memandang perlu untuk mengembangkan pembelajaran CAI-Kontekstual pada mata kuliah Kapita Selekta Matematika SMA untuk meningkatkan kemampuan berpikir matematik dan karakter mahasiswa. Pada Tahun I (2015) diperoleh hasil pengembangan pembelajaran CAI-Kontekstual yang berpotensi efektif dalam meningkatkan kemampuan berpikir matematik dan karakter mahasiswa peserta mata kuliah Kapita Selekta Matematika SMA. Hasil pengembangan tersebut, pada Tahun II (2016) diimplementasikan untuk mengetahui pengaruhnya terhadap kemampuan berpikir matematik dan karakter mahasiswa.

Berpikir matematik menurut Sabandar (2007) meliputi: mengingat (hafalan), memahami, dan pemecahan masalah matematik. Lithner (Mujib, 2011) mengklasifikasikan berpikir hafalan menjadi dua kelompok utama, yaitu penalaran hafalan (memorized reasoning) dan penalaran algoritmik (algorithmic reasoning). Sedangkan kemampuan pemahaman matematis menurut Herdian (2010) adalah salah satu tujuan penting dalam pembelajaran, memberikan pengertian bahwa materi-materi yang diajarkan kepada siswa bukan hanya sebagai hafalan, namun lebih dari itu dengan pemahaman siswa dapat lebih mengerti akan konsep materi pelajaran itu sendiri. Pemahaman matematis juga merupakan salah satu tujuan dari setiap materi yang disampaikan oleh guru, sebab guru merupakan pembimbing siswa untuk mencapai konsep yang diharapkan Ini berarti pengertian esensi dari pemahaman adalah memahami tentang situasi yang sedang dihadapi dan dapat mengungkapkan serta menjelaskan maksud yang terkandung di dalamnya. Sementara masalah matematik menurut Cooney, et al (Shadiq, 2004) sebagai berikut: “...for a question to be a problem, it must present a challenge that cannot be resolved by some routine procedure known to the student." Ini berarti bahwa tidak semua pertanyaan merupakan masalah bagi seseorang apabila orang tersebut mau mencari solusinya. Termuatnya "tantangan" serta "belum 
diketahuinya prosedur rutin" pada suatu pertanyaan yang akan diberikan kepada mahasiswa akan menentukan terkategorikannya suatu pertanyaan menjadi "masalah".

Berkaitan dengan karakter, BPP Puskur (2010) menjelaskan bahwa karakter adalah watak, tabiat, akhlak, atau kepribadian seseorang yang terbentuk dari hasil internalisasi berbagai kebajikan (virtues) yang diyakininya dan digunakannya sebagai landasan untuk cara pandang, berpikir, bersikap, dan bertindak. Sedangkan pendidikan karakter bangsa adalah pendidikan yang mengembangkan nilai-nilai karakter bangsa pada diri peserta didik sehingga mereka memiliki dan menerapkan nilai-nilai tersebut dalam kehidupan dirinya, sebagai anggota masyarakat, dan warga negara yang religius, nasionalis, produktif, dan kreatif.

Turmudi (2011) menjelaskan bahwa seringkali matematika hanya dipahami sebagai rumus-rumus, aturan, dan algoritma yang kebenarannya mutlak, dan tidak dapat dipertanyakan tentang ke-mengapa-annya. Pemahaman matematika yang seperti ini hanya akan membelenggu pengguna matematika saja, menghambat pemahaman bahwa matematika sebenarnya bermakna (meaningful) dan berguna (useful). Hal ini dikarenakan menurut Freudenthal (Turmudi, 2011) kehidupan sosial seringkali memanfaatkan prinsip-prinsip matematika, sebab pada hakekatnya matematika merupakan aktivitas kehidupan umat manusia. Hal ini menunjukkan bahwa pembelajaran matematika berpotensi untuk membentuk karakter bangsa.

Berkaitan dengan pembelajaran, seiring dengan semakin majunya Teknologi Informasi dan Komunikasi (TIK) telah mengubah model dan pola pembelajaran pada dunia pendidikan pada saat ini. Ditegaskan dalam Peraturan Menteri Pendidikan dan Kebudayaan Republik Indonesia nomor 68 tahun 2014 bahwa dalam rangka mewujudkan suasana pembelajaran dan proses pembelajaran aktif, diharapkan guru memanfaatkan berbagai sumber belajar agar potensi peserta didik dapat dikembangkan secara maksimal;untuk mewujudkan situasi pembelajaran yang mendukung potensi peserta didik perlu di dukung dengan pemanfaatan teknologi informasi dan komunikasi yang dapat mengeksplorasi 
sumber belajar secara efektif dan efisien. Salah satu pembelajaran dengan pemanfaatan TIK adalah pengajaran berbantuan komputer atau Computer Aided Instruction (CAI). Menurut Darmawan (2010), program CAI merupakan program pembelajaran yang digunakan dalam proses pembelajaran dengan menggunakan perangkat lunak berupa program komputer yang berisi materi pelajaran. Sementara Harjanto (2012) menjelaskan bahwa model-model CAI terdiri dari: Drill and practice, simulasi, tutorial, dan permainan.

Model CAI yang dikembangkan dalam penelitian ini adalah model Tutorial berbasis kontekstual. Hal ini mengingat beberapa kekhususan seperti: Tingkat abstraksi dan penalaran yang tinggi, serta penerapan matematika, yang semua itu akan lebih mudah dipelajari melalui pendekatan tutorial lewat komputer. CAI Tutorial dalam penelitian ini digambarkan dalam Flow charts sebagai berikut.

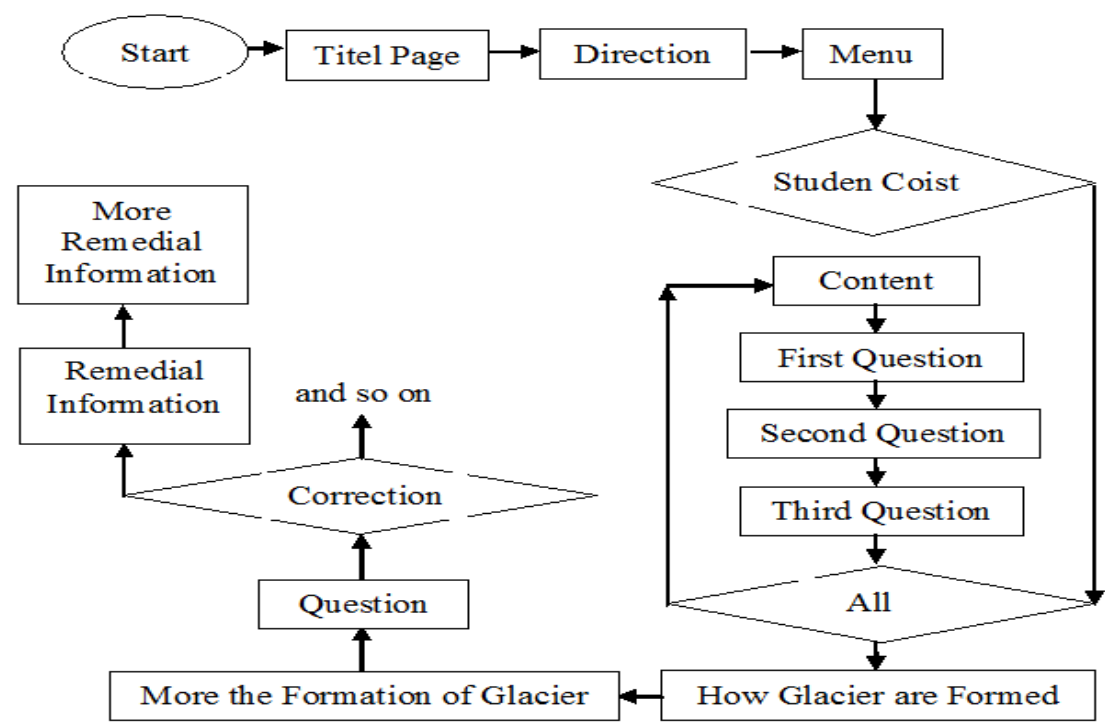

Gambar 1. Flow charts CAI Tutorial (Sumber: Darmawan, 2010)

Model flow chart pada Gambar 1 di atas merupakan model Flow charts yang sudah disesuaikan dengan kebutuhan informasi pembelajaran yang akan disajikan untuk sebuah topik pembelajaran dengan model tutorial.

Sesuai dengan latar belakang masalah di atas, masalah dalam penelitian ini adalah apakah pembelajaran CAI-Kontekstual berpengaruh terhadap kemampuan berpikir matematik dan karakter mahasiswa keguruan peserta mata 
kuliah Kapita Selekta Matematika SMA? Tujuan penelitian ini adalah untuk mengetahui pengaruh pembelajaran CAI-Kontekstual terhadap kemampuan berpikir matematik dan karakter mahasiswa keguruan peserta mata kuliah Kapita Selekta Matematika SMA. Secara umum, hasil dari penelitian ini diharapkan dapat bermanfaat bagi perkembangan pendidikan matematika, yaitu sebagai masukan dalam memilih alternatif inovasi model pembelajaran matematika yang dapat mengembangkan kemampuan berpikir matematik dan karakter mahasiswa keguruan sehingga dapat meningkatkan kualitas perkuliahan matematika.

Salah satu penelitian yang sudah dilaksanakan oleh penulis adalah mengenai implementasi pembelajaran kontekstual menggunakan powerpoint dalam upaya meningkatkan pemahaman matematik mahasiswa SMP. Hasilnya antara lain:pembelajaran kontekstual dengan menggunakan powerpoint dengan cara “ siswa secara berkelompok mengerjakan LKS dan dibimbing guru cara mengubah soal cerita ke dalam bentuk model matematika" dapat meningkatkan KPM siswa dari PAM dengan kriteria tinggi (Nanang, 2013). Oleh karena itu, upaya pengembangan powerpoint ke arah multimedia interarktif harus terus dilakukan, agar memberikan hasil yang sesuai dengan harapan. Selain itu, diharapkan guru dan mahasiswa dapat memanfaatkan teknologi khususnya TIK.

\section{METODE PENELITIAN}

Penelitian merupakan research and development $(R \& D)$. Menurut Sugiyono (2012), R\&D pendidikan adalah sebuah proses yang digunakan untuk mengembangkan dan memvalidasi produk pendidikan. Model R\&D dalam pendidikan sebagai "a process used to develop and validate educational product". Setelah melalui pengembangan CAI-Kontekstual, dalam penelitian ini penulis melakukan: (1) Menelaah pengaruh penerapan CAI-Kontekstual terhadap kemampuan berpikir matematik dan karakter mahasiswa Pendidikan Matematika STKIP Garut Tahun Akademik 2015/2016 ditinjau dari level pengetahuan awal mahasiswa dan (2) Menelaah keterkaitan antara pengetahuan awal, kemampuan berpikir matematik, dan karakter mahasiswa. 
Dalam uji validasi ini, penulis membagi mahasiswa kedalam dua kelompok. Satu kelompok menjadi kelompok eksperimen (mendapatkan pembelajaran CAI-Kontekstual) dan satu kelompok lagi menjadi kelompok kontrol (mendapatkan pembelajaran konvensional). Baik itu kelompok eksperimen maupun kelompok kontrol pertama diberi tes Pengetahuan Awal Matematika (PAM). Selanjutnya kedua kelompok tersebut mengalami proses pembelajaran, kemudian diberikan tes yang sama sebagai tes akhir. Tahap selanjutnya adalah melakukan analisis statistik uji perbedaan dua rata terhadap (1) hasil tes akhir kelompok eksperimen dengan kelompok kontrol dan (2) hasil pengukuran skala karakter pada kelompok eksperimen dengan kelompok kontrol.

Instrumen penelitian yang digunakan berupa soal kemampuan berpikir matematik yang terdiri dari tiga jenis soal, yaitu soal kemampuan hafalan, pemahaman, dan pemecahan masalah matematik. Setelah mahasiswa kelompok eksperimen dan kontrol mengerjakan seluruh soal, mahasiswa tersebut diminta untuk mengisi angket/skala yang berisi pernyataan-pernyataan untuk mengukur karakter mahasiswa.

Populasi dalam penelitian ini adalah mahasiswa program studi pendidikan matematika STKIP Garut Tingkat II Semester 3 dan 4 (semester 3 untuk keperluan uji terbatas dan uji luas, sedangkan semester 4 untuk keperluan uji validasi atau eksperimen), dengan pertimbangan bahwa mahasiswa kelas ini akan menerima mata kuliah Kapita Selekta Matematika SMA. Terhadap populasi itu dilakukan sampling. Penetapan sampel dilakukan secara random yakni memilih secara acak dua kelas dari tiga kelas yang ada. Setelah proses uji coba terbatas dan uji coba luas berakhir, kemudian dilakukan uji validasi model (eksperimen). Uji validasi ini dilakukan pada semester 4 Tahun Akademik 2015/2016. Dalam uji validasi model terdapat kelompok eksperimen maupun kontrol. Kelompok eksperimen mendapatkan treatmen dengan model pembelajaran yang dikembangkan yaitu CAI-Kontekstual, sedangkan kelompok kontrol perkuliahan secara konvensional. Prosedur pengambilan sampelnya dapat dilihat pada Gambar 2 berikut. 


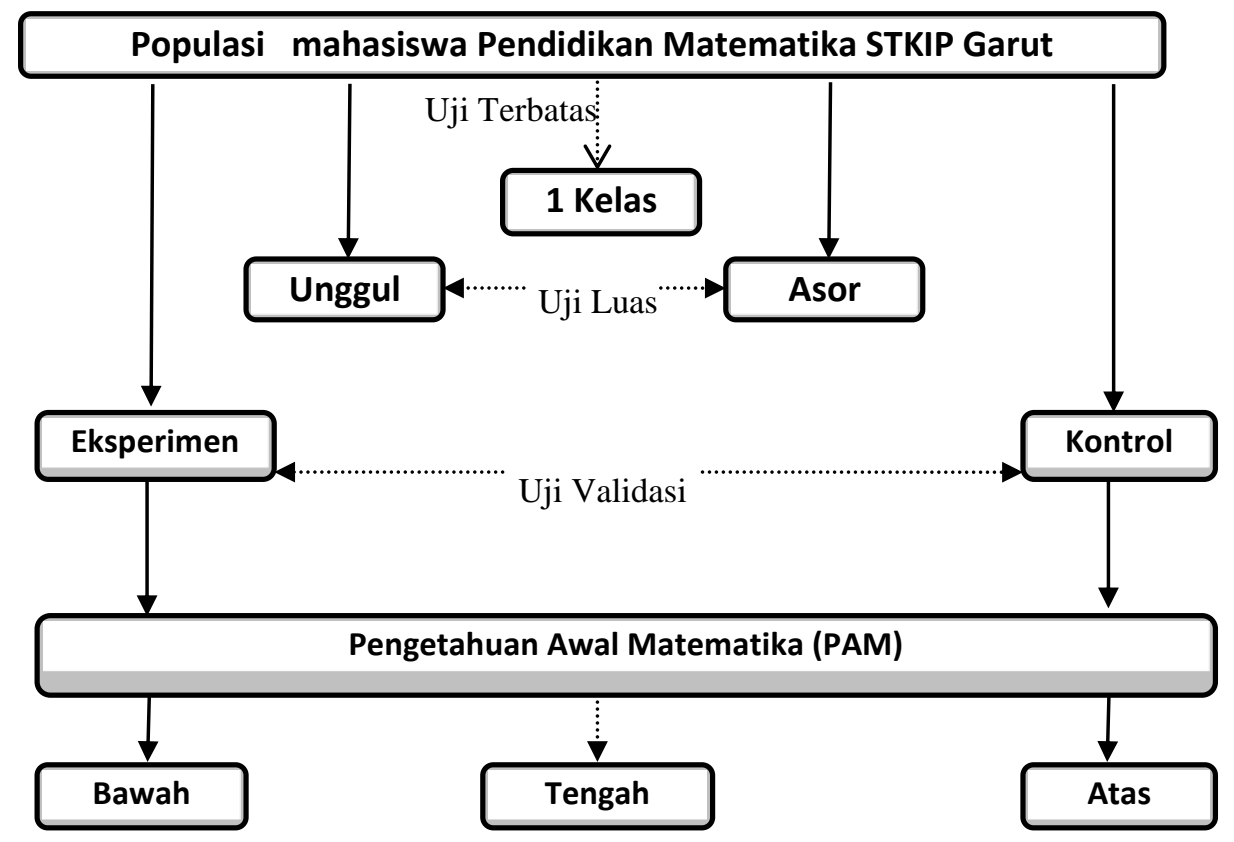

Gambar 2. Prosedur Pengambilan Sampel Penelitian

Pada tahap penelitian uji validasi digunakan analisis kuantitatif dan kualitatif. Analisis kuantitatif dengan uji perbedaan dua rata-rata hasil tes antara kelompok eksperimen dan kontrol. Analisis kualitatif dilakukan untuk melihat peningkatan kinerja dosen jika menggunakan model pembelajaran yang di kembangkan. Seluruh analisis data dilakukan dengan menggunakan program SPSS. Penilaian jawaban terhadap kedua tes yaitu tes pengetahuan awal matematika (PAM) dan tes kemampuan berpikir matematik untuk setiap mahasiswa dinilai dengan berpedoman kepada aturan penilaian (rubrik penskoran). Tes PAM dinyatakan sebagai tes awal, sedangkan tes kemampuan berpikir matematik (yang terdiri dari tes kemampuan hafalan, pemahaman, dan pemecahan masalah matemtik) dinyatakan sebagai tes akhir. Skor yang diperoleh mahasiswa dikelompokkan menurut kelompok model pembelajaran (CAIKontekstual dan konvensional). Karakter setiap mahasiswa dinilai sesuai dengan aturan penyekoran skala sikap. Skor total karakter mahasiswa yang diperoleh pada penelitian ini merupakan data interval, karena skor options yang dipilih mahasiswa sebagai kecenderungan karakternya, merupakan pembulatan dari skor karakter mahasiswa yang sesungguhnya. Skor total karakter yang diperoleh setiap 
mahasiswa juga dikelompokkan menurut kelompok model pembelajaran dan kelompok pengetahuan awal mahasiswa. Analisis data dilakukan sesuai permasalahannya.

Ada dua tahapan utama pengolahan data untuk suatu masalah dalam penelitian ini, yaitu: Pertama, menguji semua persyaratan statistik yang diperlukan sebagai dasar dalam rangka pengujian hipotesis. Persyaratan statistik yang diuji terlebih dahulu adalah uji normalitas sebaran data subjek sampel penelitian masing-masing kelompok pembelajaran, baik untuk bagian-bagiannya maupun untuk gabungannya. Homogenitas varians antara kelompok sesuai permasalahannya. Untuk uji perbedaan dua rerata Uji-t dan Uji-t' untuk kelompok sampel yang variansnya tidak homogen.

\section{HASIL DAN PEMBAHASAN}

Rangkuman hasil pengelompokan kategori PAM (Bawah, Tengah, Atas) mahasiswa berdasarkan kelompok kontrol dan eksperimen tampak pada Tabel 2 sebagai berikut.

Tabel 2. Pengelompokan PAM mahasiswa

\begin{tabular}{cccc}
\hline PAM & Kontrol $($ PKV) & Eksperimen (PCK) & Total \\
\hline Bawah & 6 & 5 & 11 \\
Tengah & 19 & 20 & 39 \\
Atas & 5 & 5 & 10 \\
\hline Total & 30 & 30 & 60 \\
\hline
\end{tabular}

Tabel 2 memberikan gambaran bahwa kelompok kontrol (PKV) dan kelompok eksperimen (PCK) memiliki jumlah mahasiswa dengan PAM berkategori bawah, tengah, dan atas yang hampir sama. Hal ini berarti sebelum penerapan pendekatan pembelajaran matematika dalam penelitian ini diterapkan, secara kuantitas banyaknya kategori PAM mahasiswa dari masing-masing kelompok hampir sama. 
Data penelitian yang berkenaan dengan Kemampuan Berpikir Matematik (KBM) diperoleh melalui tes KBM pada tes akhir yang terdiri dari gabungan hasil tes Kemampuan Hafalan Matematik (KHM), Kemampuan Pemahaman Matematik (KPM), dan Kemampuan Pemecahan Masalah Matematik (KPMM). Hasil rangkuman KBM dalam data gabungan atau keseluruhan berdasarkan pendekatan pembelajaran disajikan pada Tabel 3.

Tabel 3. Rerata dan Simpangan Baku Kemampuan Berpikir Matematik

\begin{tabular}{cccccc}
\hline Kelompok & N & Rerata & $\begin{array}{c}\text { Simpangan } \\
\text { Baku }\end{array}$ & $\begin{array}{c}\text { Skor } \\
\text { Minimum }\end{array}$ & $\begin{array}{c}\text { Skor } \\
\text { Maksimum }\end{array}$ \\
\hline PKV & 30 & 11,37 & 5,20 & 4 & 24 \\
PCK & 30 & 23,27 & 6,59 & 14 & 37 \\
\hline
\end{tabular}

Catatan: Skor ideal (betul semua) tes kemampuan berpikir matematik adalah 40

Hasil analisis uji statistik tes akhir kemampuan berpikir matematik pada kelas eksperimen dan kelas kontrol memberikan hasil sebagai berikut.

Tabel 4. Rekapitulasi Uji Perbedaan Kemampuan Berpikir Matematik

\begin{tabular}{cccccc}
\hline Kelompok & $\mathbf{N}$ & Rerata & $\mathbf{t}$ & $\mathbf{d f}$ & Sig. (2-tailed) \\
\hline PKV & 30 & 11,37 & & & \\
PCK & 30 & 23,27 & -7.766 & 58 & .000
\end{tabular}

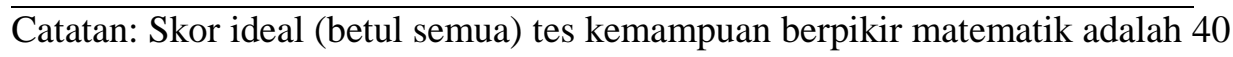

Berdasarkan Tabel 4 terlihat bahwa rata-rata kemampuan berpikir matematik mahasiswa pada kelas eksperimen lebih besar dari kelompok kontrol. Dari hasil Uji perbedaan dua rata-rata (Uji-t) pada Tabel 4 diperoleh nilai $\mathrm{t}=-7,766$ dengan nilai probabilitas (sig.) $=0,000$. Oleh karena nilai probabilitas (sig.) lebih kecil dari $\alpha=0,05$, maka terdapat perbedaan kemampuan berpikir matematik antara mahasiswa yang mendapatkan PCK dengan PKV.

Data penelitian yang berkenaan dengan karakter mahasiswa diperoleh melalui skala karakter pada akhir pembelajaran yang terdiri dari 12 pernyataan 
(setiap item pernyataan skor maksimalnya 4). Hasil rangkuman karakter mahasiswa dalam data gabungan atau keseluruhan berdasarkan pendekatan pembelajaran disajikan pada Tabel 5.

Tabel 5. Rerata dan Simpangan Baku Karakter Mahasiswa

\begin{tabular}{cccccc} 
Kelompok & N & Rerata & $\begin{array}{c}\text { Simpangan } \\
\text { Baku }\end{array}$ & $\begin{array}{c}\text { Skor } \\
\text { Minimum }\end{array}$ & $\begin{array}{c}\text { Skor } \\
\text { Maksimum }\end{array}$ \\
\hline PKV & 30 & 26,07 & 11,50 & 17 & 34 \\
PCK & 30 & 34,43 & 15,47 & 26 & 43 \\
\hline
\end{tabular}

Catatan: Skor ideal karakter mahasiswa adalah 48

Hasil analisis uji statistik pengukuran skala karakter pada kelas eksperimen dan kelas kontrol memberikan hasil sebagai berikut.

Tabel 6. Rekapitulasi Uji Perbedaan Karakter Mahasiswa

\begin{tabular}{cccccc}
\hline Kelompok & N & Rerata & t & Df & Sig. (2-tailed) \\
\hline PKV & 30 & 26,07 & $-6,862$ & 58.000 & .000 \\
PCK & 30 & 34,43 & & & \\
\hline
\end{tabular}

Catatan: Skor ideal karakter mahasiswa adalah 48

Berdasarkan Tabel 6 terlihat bahwa rata-rata skor karakter mahasiswa pada kelas eksperimen lebih besar dari kelompok kontrol. Dari hasil Uji perbedaan dua ratarata (Uji-t) pada Tabel 6 diperoleh nilai $\mathrm{t}=-6,862$ dengan nilai probabilitas (sig.) $=0,000$. Oleh karena nilai probabilitas (sig.) lebih kecil dari $\alpha=0,05$, maka terdapat perbedaan karakter antara mahasiswa yang mendapatkan PCK dengan PKV.

\section{KESIMPULAN}

Berdasarkan temuan dan analisis data yang diperoleh dari kegiatan studi pendahuluan dan uji coba model serta pembahasan hasil penelitian, diperoleh kesimpulan bahwa secara umum pembelajaran CAI-Kontekstual berpengaruh 
positif terhadap kemampuan berpikir matematik dan karakter mahasiswa peserta mata kuliah Kapita Selekta Matematika SMA.

\section{DAFTAR PUSTAKA}

BPP Puskur, Pengembangan Pendidikan Budaya dan Karakter Bangsa: Bahan Pelatihan Penguatan Metodologi Pembelajaran Berdasarkan Nilai-nilai Budaya untuk Membentuk Daya Saing dan Karakter Bangsa, Kementrian Pendidikan Nasional, Jakarta, 2010.

Darmawan, D., Pemrograman Pembelajaran Berbasis Computer Assisted Instruction, PT Remaja Rosdakarya, Bandung, 2010.

Depdiknas, Kurikulum Matematika SMP/M.Ts., Dirjen Manajemen Dikdasmen, Jakarta, 2006.

Driver, R., A Constructivist View of Learning: Children's Conceptions and Nature of Science, in What Research Says to the Sciences Teacher, National Sciences Teacher Asosiation, Washington, 1993.

Harjanto, A., Rancang Bangun Computer Assisted Instruction (CAI) sebagai Media Pembelajaran dalam Mata Pelajaran Fisika Sekolah Menengah Atas, Tesis, Program Studi Magister Sistem Informasi Magister Sistem Informasi Universitas Diponegoro, Semarang, 2012.

Herdian, Kemampuan Pemahaman 2010, https://herdy07.wordpress.com/2010/05/27/kemampuan-pemahamanmatematis/, diakses pada 3 Oktober 2010.

Kemendikbud, Survey Internasional TIMSS (trends In International Mathematics and Science Study, Badan Penelitian dan Pengembangan, Jakarta, 2011.

Kesuma, D. d.k.k., Pendidikan Karakter: Kajian Teori dan Praktik di Sekolah, PT. Remaja Rosda Karya, Bandung, 2011.

Mujib, A., Analisis Penalaran dalam Ujian Nasional Matematika SMA/MA Program IPA Tahun Pelajaran 2011/2012, Laporan Akhir Penelitian, Universitas Muslim Nusantara (UMN) Al-Washliyah, 2011. 
Nanang, Pemahaman Matematik melalui Pembelajaran Kontekstual menggunakan Powerpoint, Wawasan Tridharma, Majalah Ilmiah Kopertis Wilayah VII, 12(5) (2013). 36-44.

Sabandar, J., Berpikir Reflektif, Seminar Tingkat Nasional FPMIPA UPI Bandung: tidak diterbitkan, 2007.

Shadiq, F., Pemecahan Masalah, Penalaran dan Komunikasi, Diklat Instruktur/Pengembang Matematika SMA Jenjang Dasar, PPPG Matematika Yogyakarta, 2004.

Siswono, T.Y.E., Membangun Karakter Pemelajaran Matematika, Lambung Mangkurat, Banjarmasin, 2012.

Sugiyono, Metode Penelitian Pendidikan (Pendekatan Kuantatif, Kualitatif, dan $R \& D)$, Alfabeta, Bandung, 2012.

Suprijono, A., Cooperative Learning: Teori dan Aplikasi Paikem, Pustaka Pelajar, Yogyakarta, 2014.

Turmudi, Membangun Karakter melalui Pemodelan Matematika, Pendidikan Karakter: Nilai Inti Bagi Upaya Pembinaan Kepribadian Bangsa, Widaya Aksara Press-Lab PKn UPI, Bandung, 2011.

Wahyudin, Filsafat dan Model-Model Pembelajaran Matematika, Mandiri, Bandung, 2012.

Yaniawati, R.P., E-Learning: Alternatif Pembelajaran Kontemporer, Arfino Raya, Bandung, 2010. 
